\title{
Private Protected Areas in Latin America: Between conservation, sustainability goals and economic interests. A review
}

\author{
Benedikt Hora, Carla Marchant \& Axel Borsdorf
}

Keywords: private mountain protected areas, local development, conservation

\section{Abstract}

Worldwide, but particularly in Latin America, private protected areas (PPAs), including in mountain areas, have become increasingly numerous. In some Latin American countries, PPAs complement the public protected areas to a significant degree. Beneficiaries of these private protection initiatives, which often close gaps in fragmented biomes, may be governments or eco-tourism operators. Drawbacks of PPAs are the lack of clear definitions and ownership, the absence of suitable management, green grabbing, and limited government support. This article gives an overview of PPAs in mountain regions and presents the most important literature published so far.

\section{Introduction}

Worldwide, a trend towards privatization can be observed (Jeanetti 2008). Even in countries with a strong market tradition, many services are being contracted out to the private sector, justifying this development in terms of effectiveness, cost efficiency, and the generally poor performance of public agencies (Donahue 1989; Kramer et al. unpublished). These trends are motivated by the hope that market incentives may reduce costs and encourage innovations. Castree (2008) coined the term neoliberalization of nature to refer to the current trend that seeks to apply market forces to natural spaces, demonstrating that the environment does not escape these trends.

Traditionally nature protection, conservation and regional development have been the concern of public authorities (Langholz \& Lassoie 2001), as normally the implementation of protected areas needed public financing and was not regarded as a business. However, the privatization trend reached nature conservation in the late 1980s (Holmes 2015). In many countries, private actors declared land as a protected area, bought land to create such sites, or even took over the control of former national parks. Igoe and Brockington (2007) argue that the neo-liberalization of conservation involves the regulation of nature through commodification.

Rivera and Vallejos (2015) showed that one central point of global politics in conservation was the emergence of large non-governmental environmental organizations of global influence, including Conservation International, The Nature Conservancy (TNC), the World Wide Fund for Nature (WWF) and the World Resources Institute (Zimmerer et al. 2004). These new actors in the field of international policy play a key role in conservation and are closely linked with the creation of private parks.

However, the private sector, or public-private partnerships, can offer a number of advantages for protected area operations and management: they can provide financial and technical resources, contribute to marketing and sustainable self-financing, and bring operational expertise to the competitive industry of international nature tourism.

Furthermore, many studies have demonstrated the private sector's increasing role in biodiversity conservation (Edwards 1995; Merrifield 1996; Krug 2001). Following the recent opening of private protected areas (PPAs) in some states, the commitment by other countries to expand the total combined protected areas in a representative and well-connected manner, as part of the Convention on Biological Diversity's Aichi Target 11, will require the inclusion of a range of protection mechanisms over a variety of tenures, including strengthening the status of protected areas over private land (Woodley et al. 2012).

The aim of this article is to give a critical review of this new kind of protected areas, and to analyse whether the liberal movement of the state towards private initiatives may lead to enhanced conservation and protection of critical biodiversity, labile ecology, increased participation by citizen, and sustainable development. We will look specifically at mountain protected areas in the Latin American context. Mountains are important as ecosystem service providers, are often hotspots of biodiversity, strongly affected by the effects of climate change and globalization, and influenced by the land demands of amenity migrants. They also attract visitors with specific interests in nature, bird watching, hiking, biking, rafting and climbing, among other activities (Viviroli et al. 2011).

This paper seeks to answer the following questions: What is the current state of private conservation in mountain areas? Is it possible to identify global trends in this phenomenon? What are the advantages and disadvantages of this model of conservation in mountain areas?

\section{Methodology}

From a methodological perspective, this article was conceived as a narrative review, that is "a kind of publication that aims to describe and discuss the state of the science of 


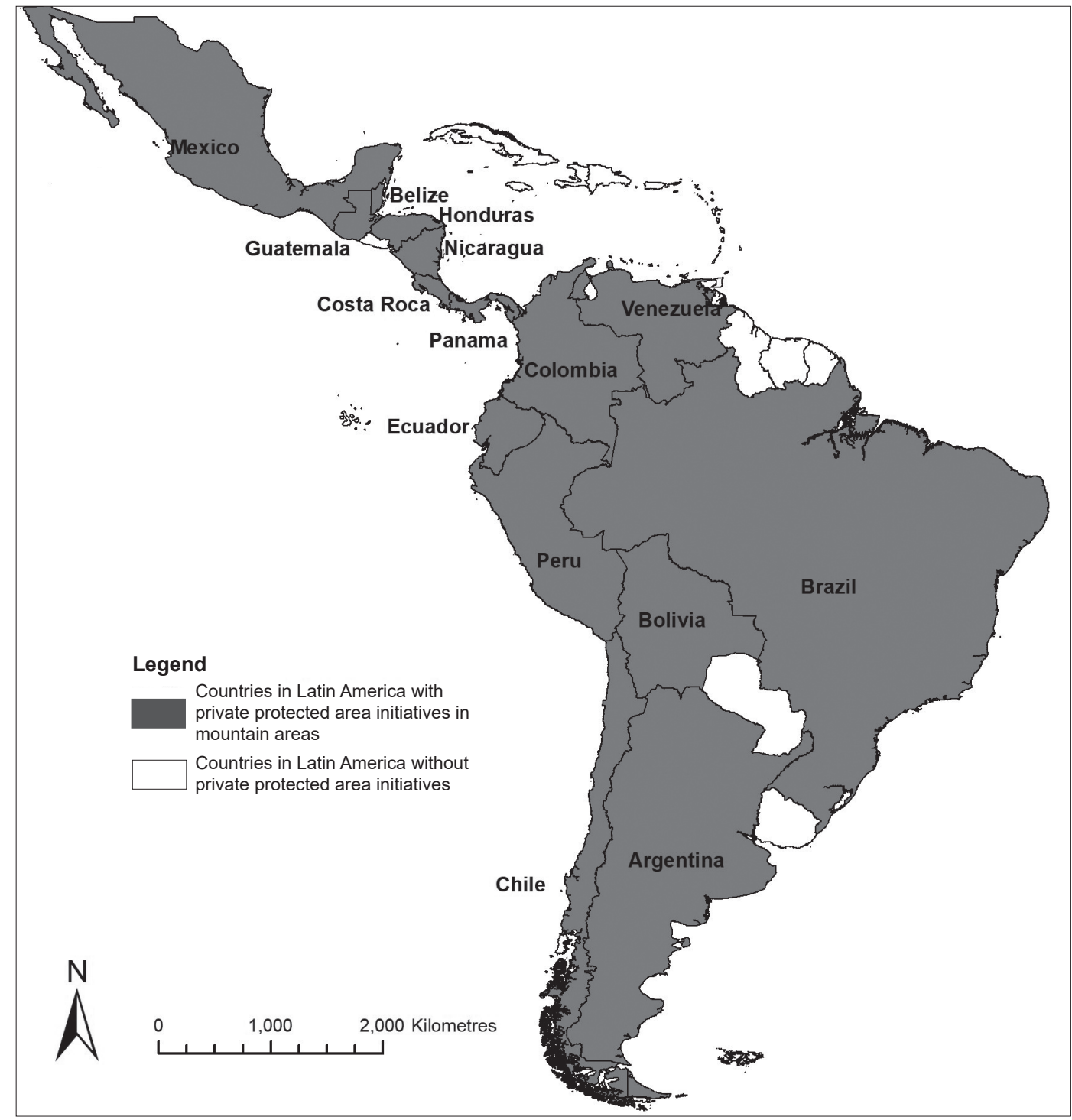

Figure 1 - Countries where Private Protected Areas are found in significant numbers. Data source: IUCN \& UNEPWCMC 2014 The World Database on Protected Areas Cambridge, UK: UNEP-WCMC. Modified by the Authors

a specific topic or theme from a theoretical and contextual point of view" (Rother et al. 2007). To achieve this goal, various bibliographic databases, such as the Web of Science, ScienceDirect, Scopus, Google Scholar among others, were considered. The main search strategy was to identify articles which contain primary keywords (Private Protected Areas, nature conservation) and to delimit our search; we drew on the World Database on Protected Areas (IUCN / UNEP 2014), which allowed us to focus on countries where this phenomenon has been already described. Following this strategy, we identified more than 60 studies for this review.

\section{Definition of PPAs}

The term private protected area, although increasingly used, still suffers from the lack of a clear and concise definition. The IUCN defines a PPA as "a land parcel of any size that is predominantly managed for biodiversity conservation, protected with or without formal government recognition and is owned or otherwise secured by individuals, communities, corporations, or non-governmental organizations" (IUCN 2005; Brent 2005).

PPAs are also called Private Reserves, Nature Reserves (for example in Colombia the Reservas Naturales de la Sociedad Civil (Society Nature Reserves)) or Ecological Reserves. They are initiated and managed by individuals, corporations and other private bodies. In many cases, the main objective is to preserve biodiversity. However, some have more specific aims, such as to secure the protection of specific endangered species, or of complete habitats, such as the páramos (alpine tundra ecosystems) of Colombia. The sizes of PPAs vary from less than 1 ha to several thousand ha.

\section{State-of-the-art}

Among the first authors to recognize private-sector involvement in nature conservation were Alderman (1994) and Langholz (1996). Alderman dealt with the 
Table1 - Selected countries in Latin America which have private protected areas. Source: The Authors

\begin{tabular}{|c|c|c|c|c|c|c|c|}
\hline Country & Legal status & \begin{tabular}{|l} 
Total sur- \\
face area \\
[ha]
\end{tabular} & Ownership & \begin{tabular}{|l|}
$\begin{array}{l}\text { For } \\
\text { profit }\end{array}$ \\
\end{tabular} & \begin{tabular}{|l|} 
Not for \\
profit
\end{tabular} & \begin{tabular}{|l} 
Payment for \\
ecosystem \\
services
\end{tabular} & $\begin{array}{l}\text { Area of PPAs as } \\
\% \text { of the country's } \\
\text { total surface area }\end{array}$ \\
\hline $\begin{array}{l}\text { Argentina (in the } \\
\text { Andes only) }\end{array}$ & $\begin{array}{l}\text { recognition by state, prov- } \\
\text { ince, commune or NGO }\end{array}$ & 152247 & $\begin{array}{l}\text { NGOs, private } \\
\text { individuals, firms }\end{array}$ & yes & yes & no & 0.054 \\
\hline Belize & recognition by state & 130663 & NGOs & yes & yes & no & 5.7 \\
\hline $\begin{array}{l}\text { Brazil (in the Mata } \\
\text { Atlantica only) }\end{array}$ & $\begin{array}{l}\text { legal basis in } 11 \text { federal } \\
\text { states }\end{array}$ & 899471 & $\begin{array}{l}\text { NGOs, communes, } \\
\text { private individuals }\end{array}$ & yes & yes & no & 0.1 \\
\hline Chile & $\begin{array}{l}\text { recognition by state, prov- } \\
\text { ince, commune or NGO }\end{array}$ & 1651916 & $\begin{array}{l}\text { NGOs, communes, } \\
\text { persons }\end{array}$ & yes & yes & no & 2.2 \\
\hline Colombia & weak control & 25590 & $\begin{array}{l}\text { NGOs, private } \\
\text { individuals }\end{array}$ & yes & yes & no & 0.02 \\
\hline Costa Rica & legal status & 264228 & $\begin{array}{l}\text { indigenous com- } \\
\text { munities, private } \\
\text { individuals, NGOs, } \\
\text { firms }\end{array}$ & yes & yes & yes & 5.19 \\
\hline Guatemala & legal status & 48098 & NGOs & no & yes & yes & 0.44 \\
\hline Honduras & no legal basis & 45000 & NGOs & & & no & 0.4 \\
\hline Mexico & legal basis & 404000 & $\begin{array}{l}\text { indigenous com- } \\
\text { munities, private } \\
\text { individuals, NGOs, } \\
\text { firms }\end{array}$ & & & no & 0.2 \\
\hline Nicaragua & legal status & 5534 & NGOs & yes & yes & no & 0.04 \\
\hline Panama & no legal basis & 40000 & NGOs & & & & 0.5 \\
\hline Peru & no legal basis & 564536 & $\begin{array}{l}\text { NGOS, firms, pri- } \\
\text { vate individuals }\end{array}$ & yes & yes & no & 0.06 \\
\hline Venezuela & no legal basis & 443000 & NGOs & yes & yes & no & 0.48 \\
\hline
\end{tabular}

economics and role of privately-owned lands for nature conservation in general, whereas Langholz analysed PPAs in Africa and Latin America. Until then, recognition of the role of PPAs had suffered from sparse data and loose definitions, and the PPAs themselves lacked integration with other protected area networks (Holmes 2013; Stolton et al. 2014; Fitzsimons 2015).

General overviews and thematic focuses were provided by IUCN $(2005,2014)$, Langholz and Lassoie (2001), Mitchell (2005), Pasquini et al. (2011), and Stolton et al. (2014). Kramer et al. (unpublished) offer a conceptual framework derived from an initial assessment of the strengths and weaknesses of the privately run protected areas. Ladle et al. (2014) formulated key challenges for PPAs.

The Costa Rican Conservation Association (Asociación 2008) and specifically Solano and Chacón (2008) provided overviews on the development of PPAs in Latin America. The first presentations of Latin American PPAs were presented by Swift et al. (1999) and Piskulich (2001). Chacón and Maldonado (2001) compared the legal frameworks in Chile and Costa Rica.

Within their studies of Biosphere Reserves and the Regional Geography of Colombia, Borsdorf, Marchant and others adressed the topic of privately owned protected areas and discussed their legal status (Borsdorf 2011; Borsdorf \& Mergili 2011; Borsdorf et al. 2011; Borsdorf et al. 2013; Borsdorf \& Marchant 2013a, b; Marchant \& Borsdorf 2013; Borsdorf 2016). Initial overviews of the Chilean experience ware given by Sepúlveda and García (1997), Maldonado (1999), and Holmes (2014, 2015). Hora and Marchant (2015) showed how a private park (the Oncol Park) may support the local economy; Sánchez (2016) demonstrated the value of a community-owned protected area to protect ancestral lands. Hora (2017) gives a deeper insight into the goals and management of a familyowned private protected area, the Huilo Huilo Biological Reserve.

\section{Distribution in Latin America}

According to IUCN/UNEP, in 2014 there were PPAs in the following Latin American countries: Mexico, Colombia, Brazil and Chile.

For the present review, other countries with sufficient data available were also taken into account because of their different approaches (SERNANP 2017; Stolton 2014; Solano \& Chacón 2005: 3-5). These countries are Belize, Honduras, Guatemala, Costa Rica, Venezuela, Panama, Colombia, Peru and Argentina. Table 1 lists the different countries in Latin America with PPAs.

There is considerable variety between countries with private protection initiatives in terms of the PPAs' history, development, legal status and management. Table 1 gives an overview of the status of PPAs and may serve as the basis for a preliminary classification. Data about their performance in private conservation was obtained for 14 Latin American countries. Small countries like Costa Rica and Belize have more than $5 \%$ of their territory under private protected initiatives while others have less than $1 \%$ of their territory covered by PPAs. The ownership of the PPAs 
lies mainly within non-governmental organizations, or among individuals or indigenous communities.

\section{PPAs' status and legal rights in Latin Amer- ica, by country}

\section{Colombia}

Until now, the implementation of PPAs has been a matter for civil society. There are more than 540 private parks covering a total of 70000 ha, most of them small (Monteferri \& Coll 2009).

144 PPAs are organized into a network called the Asociación Red Colombiana de Reservas Naturales de la Sociedad Civil (RESNATUR), which was founded in 1993 and is co-financed by the WWF and the Foundation for Higher Education (FES). Of these 144 PPAs, 83 are located in the Andean region and are run mainly by private individuals. They vary in size between 1 and 10 ha. In 2008, through a resolution of the Ministry of the Environment, Housing and Territorial Development, RESNATUR was recognized as the organization that unifies the Reservas Naturales de la Sociedad Civil and private conservation efforts (RESNATUR 2016).

\section{Chile}

Chile is a prominent example of a country with private protected initiatives. Since the transition to democracy at the beginning of the 1990s, there has been huge investment, especially in southern Chile, by foreign and Chilean companies and NGOs. The biggest single PPA was created by the US-American businessman and North Face founder Douglas Tompkins: the 310992 ha Parque Pumalín in the fjord lands of the Los Lagos region. A survey carried out by Nuñez-Avila et al. (2013) found that there are 308 PPAs in Chile, covering a total of 1651916 ha, or 2.1\% of Chile's surface area. These PPAs are organized into the Asociación de Iniciativas de Conservación en Areas Privadas y de Pueblos Originarios de Chile (ASI Conserva Chile A.G.), an association of owners, holders and users of private lands or of indigenous people in Chile who practise and promote the sustainable exploitation of renewable natural resources, with an emphasis on the conservation and sustainable use of biodiversity. The only way the Chilean government recognizes the PPAs is by their conversion into Nature Sanctuaries. However, there are only 19 Nature Sanctuaries.

The economic interests and ownership vary greatly between the different PPAs in Chile. Owners can be individuals, families, or a foundation linked to just one individual (e. g. Huilo Huilo, Katalapi, Tantauco); other owners are corporations (e. g. Patagonia Sur; Oncol) or NGOs. Furthermore, they vary significantly in terms of their commercial activity, from having virtually no commercial activity (e.g. Tantauco), to functioning as for-profit PPAs (e.g. Huilo Huilo; Patagonia Sur / The Cliffs).

In 2016, a law recognizing the right of conservation was enacted. This is a Chilean law consisting of the right to preserve the environmental heritage of a property, or certain attributes or functions of the land. This right is freely and voluntarily constituted by the property's owner, the legal benefit of a private individual or legal entity.

This law encourages and makes possible the formalization of private conservation initiatives that complement the role of the state in protecting the natural heritage, especially by helping to cover under-represented ecosystems, mitigating threats, thus helping to protect the biodiversity of the existing protected areas.

\section{Costa Rica}

Costa Rica has 213 PPAs covering 82045 ha (Stolton 2014), or more than $1.6 \%$ of the country. The country provides good examples of private initiatives in environmental protection in Central America. Through the project Regenwald für Österreicher, the people of Austria were able to buy 4000 ha of rainforest in Costa Rica in order to prevent it from being logged. The initiative aims to maintain biodiversity though the connection of isolated forest areas and to reduce $\mathrm{CO}_{2}$ in the atmosphere.

\section{Mexico}

PPAs in Mexico need formal approval by the government after reviewing the proposal. The government is responsible for following up on the implementation of the PPA's Management Plan and granting incentives (Chacón Marín 2005: 3). This is also the case in other Latin American (Guatemala, Costa Rica, Brazil; Chacón 2001). Very important for the formal recognition of a PPA is the existence of a management plan demonstrating the area's biological significance in the context of the National System of Protected Areas, a sound scientific basis, and the participation of all stakeholders. The main actors are land-owners. Non-profit NGOs (mostly land trusts) can propose and manage PPAs or support other land-owners by providing management plans and technical assistance.

It must be pointed out that Mexico also has a variety of private Nature Reserves, which have no government recognition or that of any other relevant organization. The advantage of these reserves is their ability to generate diverse environmental services without having to fulfil any requirements for their creation. The main disadvantage is that their existence depends on the will of the landowner, which is not practical when the priority is to develop stable, long-term conservation programmes (Chacón Marín 2005: 4).

\section{Other mountain states of Latin America}

Ecuador has 65 private protected forests, legally recognized by the government and managed by the National Corporation of Private Forests (Solano \& Chacón 2005: 3-5). In Guatemala, 102 Private Natural Reserves, covering a total of 50000 ha, have been acknowledged by the Public Authority of Protected Areas (Chacon 2005). The number of PPAs in Venezuela 


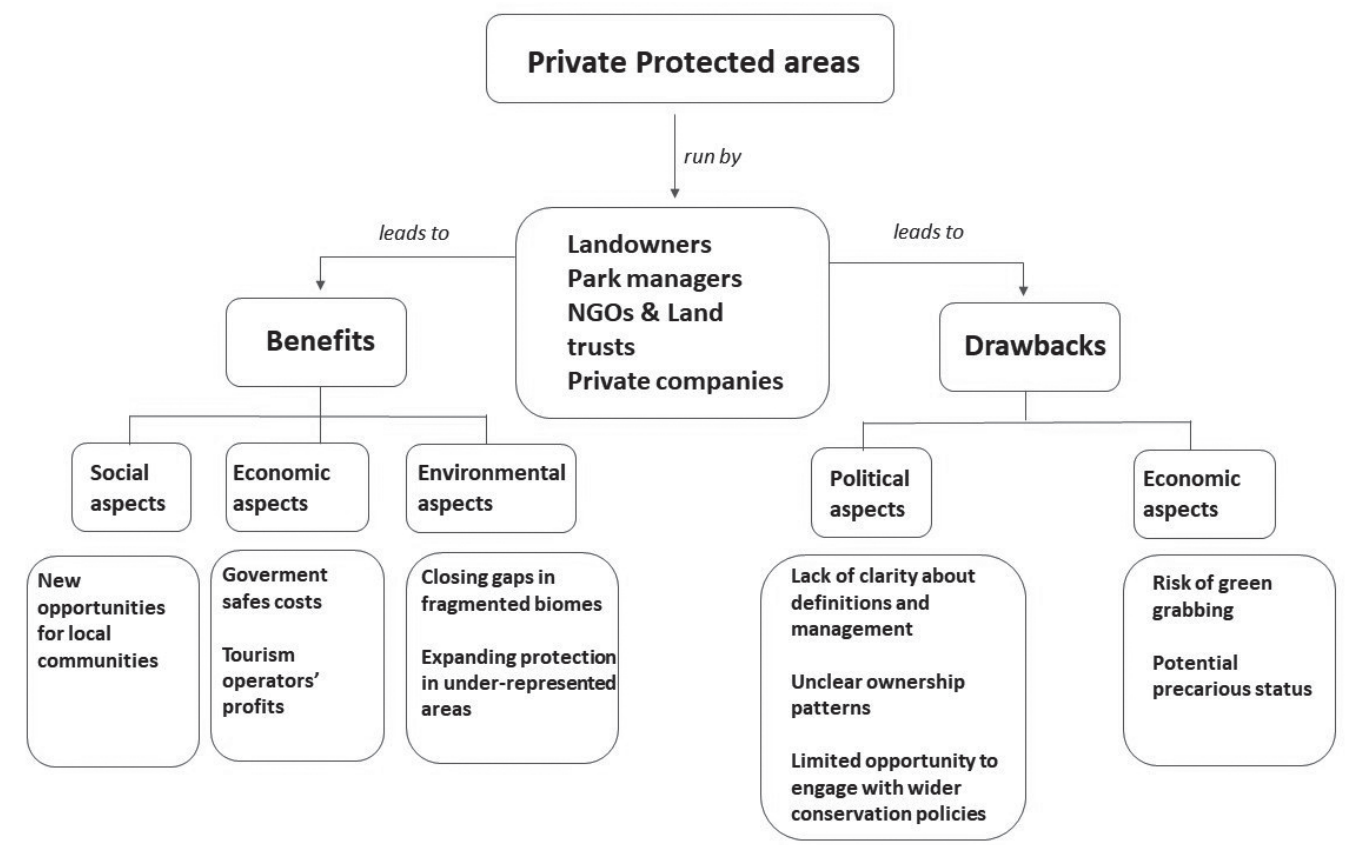

Figure 2 - Benefits and drawbacks of private protected areas. Source: The Authors

is small - just 36 properties affiliated to the association (Red Venezolana de Áreas Privadas para la Conservación de la Naturaleza). In total, APRINATURA manages an area of 443000 ha. Like Colombia, Venezuela has no legal framework for PPAs.

Like most Andean countries, Peru recognized the existence of PPAs (which in Peru are called Private Conservation Areas) relatively late. In 1997 and 2000, they were included in the legal system. 115 PPAs, covering approximately 357200 ha, are now recognized (SERNANP 2017), of which 15 are located in the Andes.

\section{Benefits and drawbacks of PPAs}

\section{Enhancement of ecosystem services}

For environmental services (including carbon fixing; provision of drinking water, hydroelectricity or agricultural services; and species maintenance for pharmaceutical, medicinal, food or cosmetic uses), disaster, erosion and sedimentation prevention payments can be provided by the government, tourism operators, agricultural producers, communities, or national or foreign companies. The government can also allow tax deductions. In the study carried out by Chacón Marín (2005: 2), privately run protected areas were three times less expensive to run than the public protected areas.

Figure 2 gives an overview of the benefits and drawbacks of PPAs. Among the possible beneficiaries are governments, who do not see certain areas as valuable land to be protected. Local populations can profit from PPAs because of increased numbers of tourists, who spend money locally. Agricultural producers in the vicinity of the PPAs can benefit from the increased biodiversity of the surrounding area. The drawbacks are that some PPAs exclude local people from access to the areas, and the appropriation of the land sometimes appears unfair. Furthermore, these initiatives can come into conflict with development projects carried out by national or regional governments (Morris 2008).

The strengths of PPAs are that they protect biodiversity in areas which are not already under governmental protection but which are under threat from land-use changes, for example forestry and / or large agricultural projects. The weaknesses of PPAs include the lack of official, institutional, recognition in some countries, and conflicts with state bodies that have different goals and interests. A further weakness is that local landholders can be banned from using local resources when PPAs are implemented by external forces, driving them out of their local livelihoods (Figure 2).

PPAs share many functions with governmental protected areas. These include climate regulation, water production, and air and water purification. Reserves often exist as biological islands, protecting the last remnants of rapidly disappearing habitats. Private conservation, as in the case of the Pumalín park, can be seen as temporary bulwarks for threatened lands, protecting them until governments become willing or able to assume responsibility for their protection (Langholz \& Lassoie 2001).

The possible disadvantage from an ecological standpoint is the potentially tenuous status of PPAs, as unlike authorized and permanently supported parks, most private reserves are informally protected. They tend to be too small to support megafauna, and for that reason tend to suffer from the fragmentation effects typical of biological islands, such as increased edge effects, introduction of exotic species, and contamination (Noss 1997). However, these effects are 
often mitigated by the fact that many PPAs border on national parks.

\section{Economic considerations}

PPAs' economic advantage is their potential profitability, especially when the area focuses on ecotourism. Economic benefit accrues not only to the landowners but also to the governments, as they can avoid costs. PPAs represent the free increase of public protected area systems, being land that governments might otherwise need to purchase and protect. Dependence on ecotourism brings with it an economic risk, because of potential fluctuations in numbers of visitors and seasonality. Furthermore, a conflict between ecological and economic concerns emerges if making a profit is placed over protection. Local tourism is enhanced by the attraction of the PPAs, as operators can organize tours to them (Langholz et al. 2000).

\section{Social and political issues}

Privately owned parks coincide with two important political themes in relation to conservation - devolution of decision making, and public participation in decision making where local resources are concerned. Local residents who own reserves can control the decision making. However, many owners of PPAs, especially the larger ones, do not live close to the areas and manage them from some distance. Another problematic issue is that PPAs tend to increase the imbalance between rich landowners and less affluent smallholders. These scenarios have been observed especially in Sub-Saharan Africa and Latin America (Langholz \& Lassoie 2001).

\section{Conclusion}

PPAs play an increasingly important role in worldwide conservation. This review article gave an overview of PPAs and their distribution within Latin America and their specific effects on the countries concerned. PPAs tend to be a feature of the mountain regions of the Americas, but they are also found in Europe, Africa, Asia and Australia. The initiatives differ significantly from country to country, in terms of their legal recognition, ownership, number and size.

Beneficiaries of PPAs include local governments, nearby populations and tourists. From an economic perspective, tourist operators, agricultural producers and ecotourism may also be beneficiaries. From an ecological perspective, advantages of PPAs include closing the gaps in fragmented biomes and expanding protection in under-represented areas. The drawbacks are the lack of a clear, internationally-recognized definition and limited government support.

While PPAs have been widely investigated in some Andean countries, other countries have still to be investigated adequately. So far, research has focused more on documentation and on legal and management issues, but critical research on conflicts between interested parties and on the additional protective effects on national park networks within individual countries is still to some extent lacking. Challenges for future research should address these issues, but even more important are the need to involve local people, impacts on the millennium sustainability goals, and the improvement of the well-being and quality of life for the inhabitants of PPAs.

\section{Acknowledgements}

This article was partially funded by Conicyt PAIMEC grant 80140004.

\section{References}

Asociación Conservación de la Naturaleza, Voluntad de Conservar (ed.) 2008. Experiencias seleccionadas de conservación por la Sociedad civil en Iberoamérica. San José, Costa Rica. [In Spanish]

Alderman, C.L. 1994. The economics and the role of privately-owned lands used for nature tourism, education and conservation. Protected Area Economics and Policy. Washington (DC).

Borsdorf, A. 2016. Peace through climate change adaptation? Experiences in the Cinturón Andino Biosphere Reserve, Colombia. In: Mainali, K. \& S. Sicroff (eds.): Jack D. Ives, Montologist. Festschrift for a mountain advocate. Lalitpur, Nepal: Himalayan Association for the Advancement of Science: 44-60.

Borsdorf, A. \& C. Marchant (eds.) 2013a. Kolumbien: Ein Land zwischen neoliberaler Öffnung und Nachhaltigkeit. Strategien der Regionalentwicklung im Zuge des Globalen Wandels anhand ausgewählter Beispiele an der Karibikkeüste. Inngeo - Innsbrucker Materialien zur Geographie 15. Innsbruck. [In German]

Borsdorf, A. \& C. Marchant 2013b. Protected areas in Colombia - on track to sustainable development? In: $5^{\text {th }}$ Symposium for Research in Protected Areas 10 to 12 June 2013, Mittersill: 77-84.

Borsdorf, A. \& M. Mergili (eds.) 2011. Kolumbien im Wandel. Erkenntnisse und Eindrücke einer dreiwöchigen Studienexkursion durch Zentral- und Südkolumbien. Inngeo - Innsbrucker Materialien zur Geographie 14. [In German]

Borsdorf, A., M. Mergili \& L.A. Ortega 2013. La Reserva de la Biosfera Cinturón Andino, Colombia. Una región modelo de estragegias de adaptación als cambio climático y de desarrollo regional sustentable? Revista de Geografía Norte Grande 55: 7-18.

Bricker, K.S., R. Black \& S. Cottrell 2012. Sustainable tourism and the millennium development goals. Burlington.

Carter, E., W.M. Adams \& J. Hutton 2008. Review: Private protected areas: Management regimes, tenure arrangements and protected area categorization in East Africa. Oryx 42: 177-186.

Castree, N. 2008. Neoliberalising nature: processes, effects, and evaluations. Environment and planning 40(1): 153-173. 
Chacón Marín, A.C. \& C. Manuel 2005. Desarrollando áreas protegidas privadas: herramientas, criterios e incentivos Developing private areas: tools, criteria and incentives. San José, Costa Rica. [In Spanish]

Chacón, C.M. \& V. Maldonado 2001. Trabajando en Marcos Jurídicos apropiados para la conservación privada. La experiencia en Chile y Costa Rica. Asunción: ARCA.

Chacon, C.M. 2005. Fostering conservation of key priority sites and rural development in Central America: the role of private protected areas. Parks 15(2): 39-47.

Cowell, S. \& C. Williams 2006. Conservation through buyer diversity: a key role for not-for-profit land-holding organizations in Australia. Ecological Management and Restoration 7: 5-20

DENR (Department of Environment and Natural Resources) 2011. Protected Areas on Private Land. Department of Environment and Natural Resources. Adelaide.

Donahue, J.D. 1989. The Privatization Decision: Public Ends, Private Means. New York.

Edwards, V. 1995. Dealing in Diversity: America's Market for Nature Conservation. New York.

Environmental Law Institute 2003. Legal tools and incentives for private lands conservation in Latin America: Building models for success. Environmental Law Institute.

Figgis, P., D. Humann \& M. Looker 2005. Conservation on private land in Australia. Parks 15: 19-29.

Galloa, J., L. Pasquini, B. Reyers \& R. Cowling 2009. The role of private conservation areas in biodiversity representation and target achievement within the Little Karoo region, South Africa. Biological Conservation 142: 446-454.

Holmes, G. 2013. What role do private protected areas have in conserving global biodiversity? SRI Papers 46 Leeds: Sustainability Research Institute (SRI), School of Earth and Environment. The University of Leeds. United Kingdom.

Holmes, G. 2015. Markets, Nature, Neoliberalism, and Conservation through Private Protected Areas in Southern Chile. Environment and Planning A 47(4): 850-866.

Hora, B. \& C. Marchant 2016. When a private park supports the local economy. In: Wymann von Dach, S., F. Bachmann, A. Borsdorf T. Kohler, M. Jurek \& E. Sharma (eds.) 2016, Investing in sustainable mountain development. Opportunities, resources and benefits. Bern: Centre for Development and Environment: 58-59.

Hora, B. 2017. Do large private protected areas contribute to sustainable development? A case study from the Huilo Huilo Biological Reserve in Neltume, Chile. eco.mont - Journal on Protected Mountain Areas Research and Manegement 9(1): 5-14.

Igoe, J. \& D. Brockington 2007 Neoliberal conservation: a brief introduction. Conservation and society 5(4): 432.

IUCN 2005 Benefits beyond Boundaries: Proceedings of the $V^{\text {th }}$ IUCN World Parks Congress. Gland and Cambridge: IUCN.

IUCN \& UNEP-WCMC 2014 The World Database on Protected Areas. Cambridge, UK: UNEP-WCMC.

Jeannetti, E. 2008 Una tendencia mundial: La pri- vatización Revista de Administración Pública 76: 45-56. [In Spanish]

Kramer, R., J. Langholz \& N. Salafsky 2002. The Role of the Private Sector in Protected Area Implementation and Management A Conceptual Framework for Analyzing Effectiveness. Unpublished document.

Krug W. 2001 Private supply of protected land in Southern Africa: A review of markets, approaches, barriers, and issues. Paper prepared for the OECD International Workshop on Market Creation for Biodiversity Products and Services; 25-26 January 2001. London, UK.

Ladle, R.J., C. Bragagnolio, G.M. Gama \& A.C.M. Mahado 2014 Private protected areas: three key challenges. Environmental Conservation 41(3): 239-240.

Langholz, J. 1996. Economics, objectives, and success of private nature reserves in Sub-Saharan Africa and Latin America. Conservation Biology 10: 271-280.

Langholz, J.A., J.P. Lassoie, D. Lee \& D. Chapman 2000. Economic considerations of privately owned parks. Ecological Economics 33(2): 173-183.

Langholz, J.A. \& J.P. Lassoie 2001. Perils and Promise of Privately Owned Protected Areas: This article reviews the current state of knowledge regarding privately owned parks worldwide, emphasizing their current status, various types, and principal strengths and weaknesses. BioScience 51(12): 1079-1085.

Langholz, J. 2010. Global trends in private protected areas and their implications for the northern Great Plains. Great Plains Research: 9-16.

Langholz, J.A. \& W. Krug. 2004. New forms of biodiversity governance: Non-state actors and the private protected area action plan. Journal of International Wildlife Law and Policy 7: 9-29.

Langholz, J.A. \& J.P. Lassoie 2001. Perils and promise of privately owned protected areas. Bio Science 51: 1079-1085.

Langholz, J., J. Lassoie, D. Lee \& D. Chapman (forthcoming). Economic Considerations of Privately Owned Parks. Ecological Economics 33(2): 173-183.

Leaman, G. \& C. Nicolson 2012. Innovative measures for establishing protected areas on private lands in South Australia. Innovation for $21^{\text {st }}$ Century Conservation. Sydney: Australian Committee of IUCN: 206-213.

Leaman, G. \& C. Nicolson 2014. Protected areas on private land: Shaping the future of the park system in Australia. In: Weber Samantha (ed.), Protected Areas in a Changing World: Proceedings of the 2013 George Wright Society Conference on Parks, Protected Areas, and Cultural Sites. Hancock, Michigan: George Wright Society: 69-76.

Lockwood, M., G. Worboys \& A. Kothari 2006. Managing Protected Areas: A Global Guide. London.

Maldonado, V. 1999. Las áreas silvestres protegidas privadas en Chile: Una herramienta para la conservación. Santiago de Chile: CODEFF.

Marchant, C. \& A. Borsdorf 2013. Protected areas in Northern Colombia - on track to sustainable development? eco.mont. Journal on Protected Mountain Areas Research and Management 5(2): 5-14. 
Merrifield, J. 1996. A market approach to conserving biodiversity. Ecological Economics 16: 217-226.

Mezquita, A. 1999. Caracterización de las Reservas Naturales Privadas en América Latina. San José. Costa Rica: Thesis, CATIE.

Mitchell, B. (ed.) 2005. Private Protected Areas in Parks: The International Journal for Protected Area Managers 15(2): 67-76.

Monteferri, B. \& D. Coll 2009 Conservación privada y comunitaria en los países amazónicos.Lima: Sociedad Peruana de Derecho Ambiental. [In Spanish]

Morris, W. 2008. Easing conservation? Conservation easement, public accountability and neoliberalism. Geoforum 39(3): 1215-1227.

Nuñez-Avila, M., E. Corcuera, A. Farias, P. Pliscoff, J. Palma, M. Barrientos \& C. Sepulveda 2013. Diagnóstico y Caracterización de Iniciativas de Conservación Privada en Chile [para proyecto MMA/GEF-PNUD 'Creación de un Sistema Nacional de Integral de Áreas Protegidas para Chile: Estructura Financiera y Operacional']. Santiago, Chile: Fundación Senda Darwin and ASI Conserva Chile A.G. [In Spanish]

Pasquini, L., J.A. Fitzsimons, S. Cowell, K. Brandon \& G. Wescott 2011. The establishment of large private nature reserves by conservation NGOs: key factors for successful implementation. Oryx 45: 373-380. doi: 10.1017/S0030605310000876.

Piskulich, Z. 2001. Incentivos para la Conservación de tierras privadas en América Latina. Arlington, USA: The Nature Conservancy.

PLCP (Private Land Conservation Program) 2016. The Running Postman. Newsletter of the Private Land Conservation Program 21. Sydney.

Rivera, C. \& A. Vallejos-Romero 2015. La privatización de la conservación en Chile: repensando la gobernanza ambiental. Bosque (Valdivia) 36(1): 15-25.

Rother, E.T. 2007 Revisão sistemática X revisão narrativa. Acta Paulista de Enfermagem 20(2): v-vi. [In Spanish]

Sánchez, R. 2016. Protecting ancestral lands. In: Wymann von Dach, S., F. Bachmann, A. Borsdorf T. Kohler, M. Jurek \& E. Sharma (eds.) 2016: Investing in sustainable mountain development. Opportunities, resources and benefits. Bern: Centre for Development and Environment: $40-41$.

Sepúlveda, C. \& D. García 1997. Cooperación público-privada como estrategia para la conservación de la biodiversidad en Chile. Ambiente y Desarrollo 13(2): 59-69.

Sims-Castley, R., G.I.H. Kerley, B. Geach \& J. Langholz 2005. Socio-economic significance of ecotourism-based private game reserves in South Africa's Eastern Cape Province. Parks 15: 6-18.

Solano, P. \& C.M. Chacón 2008. Conservación voluntaria por la sociedad civil en América Latina. In: Asociación Conservación de la Naturaleza Voluntad de Conservar (ed.) 2008: Experiencias seleccionadas de conservación por la Sociedad civil en Iberoamérica. San José, Costa.Rica: 1-6.
SERNANP 2017. Àreas de conservación privada. Lima. Available at: http://www.sernanp.gob.pe/areasde-conservacion-privada (assessed 05.01.2017) [In Spanish]

Swift, B. \& S. Bass 2003. Conservación Privada en Latinoamérica: herramientas legales y modelos para el éxito., México. D.F.: Environmental Law-Institute, Pronatura Asociación Civil. [In Spanish]

Woodley, S., B. Bertzky, N. Crawhall, N. Dudley, J.M. Londono, K. MacKinnon, K. Redford \& T. Sandwith 2012. Meeting Aichi Target 11: What does success look like for protected area systems? Parks 18(1): 23-36.

Viviroli, D., D.R. Archer, W. Buytaert, H.J. Fowler, G. Greenwood, Y. Huang, Y. Koboltschnig, L. Gernot, I. Litaor, J. López-Moreno, S. Lorentz, B. Schädler, H, Schreier, H. Hans, K. Schwaiger, M. Vuille \& R. Woods 2011. Climate change and mountain water resources: overview and recommendations for research, management and policy. Hydrology and Earth System Sciences 15(2): 471-504.

Zimmerer, K.S., R.E Galt \& M.V. Buck 2004. Globalization and multi-spatial trends in the coverage of protected-area conservation (1980-2000). Ambio: A Journal of the Human Environment 33(8): 520-529.

\section{Authors}

\section{Benedikt Hora}

studied Geography at the University of Innsbruck, Austria, and has a Master's degree in Global Change and Regional Development. He is currently a $\mathrm{PhD}$ student at the same university. His research interests are mountain science, Latin American studies and regional development. E-mail: benedikt.hora@student. uibk.ac.at

\section{Carla Marchant ${ }^{2}$}

is Assistant Professor at the Universidad Austral in Valdivia, Chile. She has a PhD in Geography from the University of Innsbruck. Her research interests are related to mountain sustainability, rural development and family farming in mountain areas.

\section{Axel Borsdorf ${ }^{1}$}

is an emeritus professor of Geography at the University of Innsbruck and the former director of the Institute for Interdisciplinary Mountain Research of the Austrian Academy of Sciences. He has carried out research in mountainous regions continuously since 1971.

${ }^{1}$ Institute of Geography, University of Innsbruck, Innrain 52f, 6020 Innsbruck, Austria.

${ }^{2}$ Institute of Environmental and Evolution Sciences, Universidad Austral de Chile. 